\title{
Potential of Biomass for Electricity Generation Using Environment- Friendly MFC
}

\section{Anand Parkash*}

Department of Chemical Engineering, Mehran University of Engineering and Technology, Jamshoro, Pakistan

*Corresponding author: Parkash A, Department of Chemical Engineering, Mehran University of Engineering and Technology, Jamshoro, Pakistan, Tel: 0333-796-2266; E-mail: parwani_anand@yahoo.com

Received date: January 22, 2018; Accepted date: January 29, 2018; Published date: February 05, 2018

Copyright: () 2018 Parkash A. This is an open-access article distributed under the terms of the Creative Commons Attribution License, which permits unrestricted use, distribution, and reproduction in any medium, provided the original author and source are credited.

\begin{abstract}
MFC had advantages over the conventional treatment of wastewater regarding nature of converting chemical energy into bio-electricity generation. The study was made for treatment of algal biomass in MFC for electricity generation. The present study deals with the utilization of sewage sludge, which contains a high level of readily biodegradable bio waste and is also one of the major sources of environmental pollution, as a substrate in MFC. Saccharomyces cerevisiae used biocatalyst and potassium ferricyanide as an oxidizer were utilized for the conversion of sewage sludge into voltage utilizing dual chambered MFC. A maximum of the voltage of $0.9-1.0 \mathrm{~V}$ was obtained per liter of the sludge with the cathode in continuous mode and the anode in batch feed mode of operation.
\end{abstract}

Keywords: Algal biomass; Electricity generation; MFC

\section{Introduction}

Microalgae are considered as promising feedstocks for the production of biofuels. Currently, the scale-up applications of algaederived biofuels are not economical yet [1]. One obvious way to reduce the cost of biofuels is to integrate them with other technologies such as waste treatment and electricity generation. Microbial fuel cells (MFCs) offer such a potential to treat waste, generate electricity and produce biofuels simultaneously [2]. In MFC, fuels, mostly organic substrates, are oxidized, electrons are generated and deposited on the anode electrode [3]. MFC employs biocatalyst, i.e., electrochemically active bacteria existing in the form of biofilm on the surface of the anode electrode. These microbes, termed exoelectrogens are capable of directly transferring and depositing electrons on the anode [4]. A substrate, both its type and concentration, is a crucial component in bio-electrochemical systems, affecting the composition of a microbial community and thus, power output [5]. In terms of power output and handling easiness, simple organic compounds including acetate are used [6]. To produce a substantial amount of electricity, however, far cheaper yet massively available feedstock should be explored. In this regard, microalgae biomass can be used. Microalgae cause pollution in the streams. They are the main sources of eutrophication. A large quantity of microalgae biomass is obtained during wastewater treatment around the world. Direct discharge of microalgae into sewer system can threaten the human health. Therefore, microalgae must be skimmed from the water bodies and disposed of. Microalgae biomass is used for biofuels production. However, the biofuels production from microalgae biomass is not economical yet. Alternatively, microalgae can be used as a substrate in MFC. This approach serves a dual purpose, waste treatment, and electricity generation. Thus, the use of microalgae biomass has two-way benefit, pollution control and feedstock for MFC. Microalgae biomass contains high level of proteins (32\%) and carbohydrates $(51 \%)$ which are readily degradable by the electro gens to produce electricity [7]. MFC are operated more sustainably in mixed culture than those in pure cultures. Clean energy can be produced by using biowaste from MFCs [8]. There are big benefits from using MFCs from biowaste: such as; safe, high efficiency, clean, low emission, quite performance and direct voltage recovery [2-4].

\section{Materials and Methods}

Two chamber MFC was fabricated by using the plastic bottles with the volume of 1 liter. The dual chambers ware joined with polyvinyl chloride (PVC) pipe, yet isolated by using salt bride, which served as a proton exchange membrane [1-4]. The anode and the cathode were of copper (15 cm long and $0.8 \mathrm{~cm}$ breadth), the anode terminal was additionally of (15 cm long and $1.6 \mathrm{~cm}$ diameter). Both cathodes were situated at a distance of $8 \mathrm{~cm}$ on either side of the salt bridge. The anode chamber was inoculated with $26 \mathrm{ml}$ sewage sludge which is rich in blende culture of microorganisms and sewage sludge collected from the hostel. The cathode was filled with potassium ferricyanide buffer $(0.3 \mathrm{M})$ had $\mathrm{pH} 7.8$, during digestion system of organic waste in the anodic chamber by Saccharomyces cerevisiae the acidic conditions existed. These conditions increasing voltage yield were considered as the steady operation of MFC.

\section{MFC configuration}

Two cubical dual-chamber reactors made of acrylic with each electrode chamber holding a volume of $112.5 \mathrm{~mL}(5.0 \mathrm{~cm} \times 5.0 \mathrm{~cm} \times$ $4.5 \mathrm{~cm}$ ) were constructed (Figure 1). Both anode and cathode had a working volume of $100 \mathrm{~mL}$ each with a headspace of $6 \mathrm{~mL}$. The chambers were purged with $\mathrm{N}_{2}$ gas to remove oxygen. Each reactor was separated by a piece of cation exchange membrane (CEM, CMI-7000, Membrane International, Inc. USA) with an effective surface area of 25 $\mathrm{cm}^{2}(5.0 \mathrm{~cm} \times 5.0 \mathrm{~cm})[6-8]$. 
Page 2 of 3

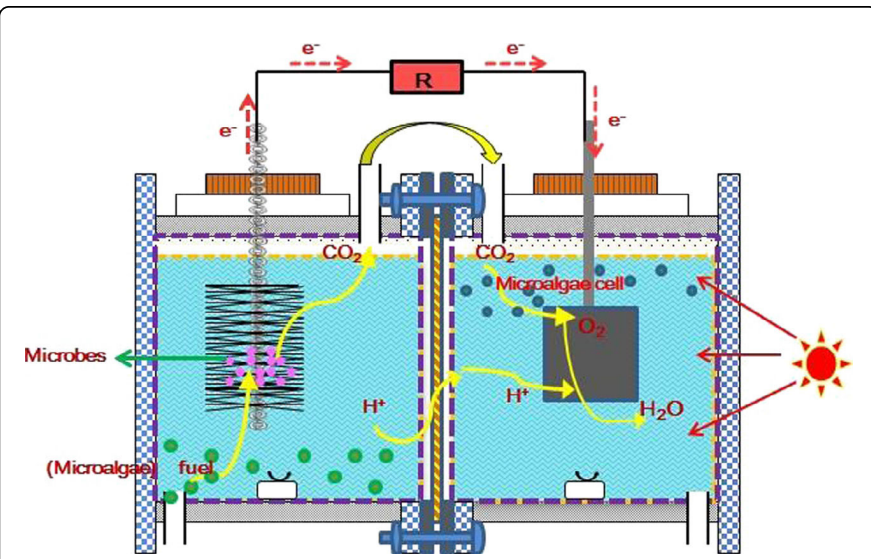

Figure 1: Schematic Configuration of Dual Chamber Microbial Fuel Cell.

\section{Results and Discussion}

All the experiments were done in two-chambered MFC. The voltage generated from MFC was controlled put by various variables, apart from the efficiency of electron exchange from microbes to cathode region, the safety of the chamber. The anodic exchange arrangement was in group encouraged mode and the cathode arrangement was in continues mode of operation. For the voltage generation, $1000 \mathrm{ml}$ of sewage sludge was encountered into the MFC, which generated a voltage of $1.06 \mathrm{~V}(0.106 \mu \mathrm{A})$ every $1000 \mathrm{ml}$ of sewage sludge (Figure 2). After 5 days of operation maximum voltage was generated, whereas afterward, it showed a gradual decrease. This decline in voltage generation probably occurred due to the substrate limitation. This implied that maximum voltage generation was related to the amount of substrate added meaning that the substrate concentration determines the amount of electricity generation from it. The result also suggested that the selected strain of microorganism was able to readily convert the organics present in the sewage sludge at their ideal proficiency bring about the exchange of a great number of electrons prompting 3.1 Current and voltage generation from algal biomass in MFC associative voltage generation.

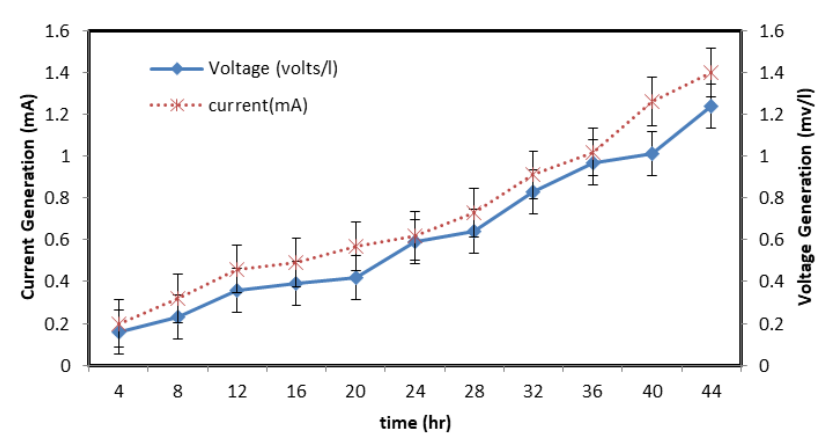

Figure 2: Current and voltage generation.

\section{Factors affecting the generation of electricity}

Impact of oxygen flow rate: Impact of oxygen flow rate on voltage generation during the running of MFC was studying using different oxygen flow rates from 20 to $200 \mathrm{ml} / \mathrm{min}$ yielding in voltage generation between $0.8 \mathrm{~V}$ and $1.0 \mathrm{~V}$ per $1000 \mathrm{ml}$ of the sewage sludge, respectively (Figure 3). These results suggested that the voltage generation increase as the air flow rate was increased and reached the maximum of around $1 \mathrm{~V}$ at oxygen flow rate of $150 \mathrm{ml} / \mathrm{min}$ before showing decline afterward. This indicates that at the higher air flow rate, voltage generation ability of MFC was substantially decreased because of the higher rate of oxygen in the air diffused to the region of the anode, which likely distributed of anaerobic microbes on the surface of the anode.

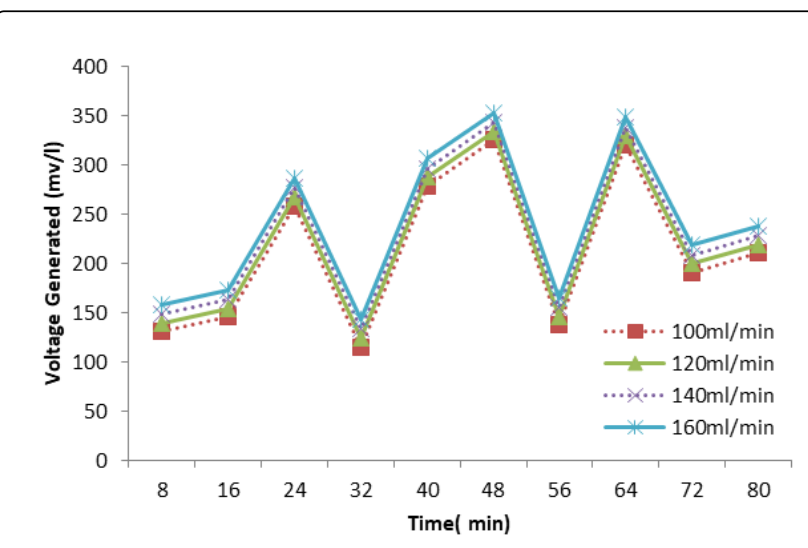

Figure 3: Effect of oxygen flow rate on current generation.

Impact of $\mathrm{pH}$ on voltage generation: $\mathrm{pH}$ is the main consideration influencing the movement of general prokaryotes. At ideal $\mathrm{pH}$, microorganisms perform natural activities of growth and digestion system the most extreme rate. The maximum yield obtained at $\mathrm{pH} 8.5$ (Figure 4), when maybe the proteins emitted by the microorganisms would have been in a conductive manifestation of ionic gathering on their dynamic destinations to capacity appropriately. Reportedly, variation in the $\mathrm{pH}$ would bring about changes in the ionic form of the active sites, which would further change the enzymatic activity leading to the variation in the reaction rate also [5]. The results additionally recommended that at $\mathrm{pH} 6$ and below, electrochemical and cellulosic activities would likely be lower when compared with the results got at higher $\mathrm{pH}$. This may be because of the denaturation of celluloses, proteins or active sites under acidic conditions. This finding was in concurrence with that reported by $\mathrm{He}$ et al. who observed that $\mathrm{pH} 7$ was suitable for cellulose degraders, as acidic conditions have a tendency to repress the growth of the greater part of cellulose degrading yeasts [2]. 
Citation: Parkash A (2018) Potential of Biomass for Electricity Generation Using Environment-Friendly MFC. J Bioprocess Biotech 8: 314 . doi:

Page 3 of 3

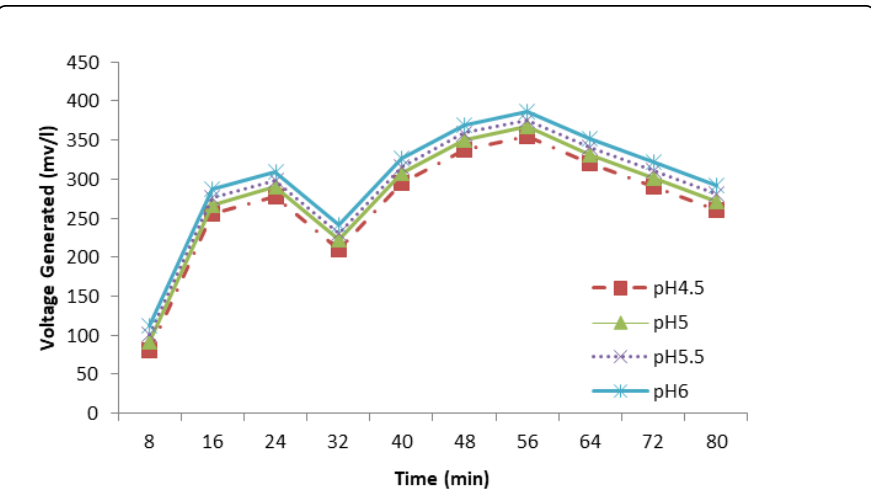

Figure 4: Effect of $\mathrm{pH}$ on the current generation.

\section{Conclusion}

Double-chambered MFC utilizing Saccharomyces cerevisiae was tried for its performance. With the anode kept up in batch and cathode chambered kept in continues mode. The MFC generated an initial voltage of $0.8 \mathrm{~V}$ and a final voltage of $1.06 \mathrm{~V}$. Data was recorded after 24 hours' time interval for 5 days. Designs of MFC need enhancements before the attractive product will be marketable. Mainly anodic materials commonly utilized as a part of MFC, for example, arranged various zinc, and others are quite expensive. Enhanced electrodes, for example, copper, zinc, and carbon, may offer a financial choice.

\section{Acknowledgements}

The authors wish to express their sincere thanks for the lab facilities provided for this work in the Department of Chemical Engineering, Mehran University of Engineering and Technology, Jamshoro.

\section{References}

1. Parkash A, Aziz S, Soomro SA (2015) Impact of Salt Concentrations on Electricity Generation using Hostel Sludge Based Duel Chambered Microbial Fuel Cell. J Bioprocess Biotech 5: 252.

2. Kumar S, Kumar HD, Babu KG (2012) A study on the electricity generation from the cow dung using microbial fuel cell. J Biochem 3: 442-447.

3. Min B, Kim JR, Oh SE, Regan MJ, Logan BE (2005) Electricity generation from swine wastewater using microbial fuel cells. Water Res 39: 4961-4968.

4. Parkash A (2016) Characterization of Generated Voltage, Current, Power, and Power Density from Cow Dung Using Double Chambered Microbial Fuel Cell. J Phys Chem Biophys 6: 208.

5. Scott K, Murano C (2007) A study of a microbial fuel cell battery using manure sludge waste. J Chem Technol Biotechnol 82: 809-817.

6. Dental SK, Strogen B, Chiu P (2004) Direct generation of electricity from sludges and other liquid wastes. Water Sci Technol 50: 161-168.

7. Rabaey K, Verstraete W (2005) Microbial fuel cells: novel biotechnology for energy generation. Trends Biotechnol 23: 291-298.

8. Parkash A (2015) Design and Fabrication of a Double Chamber Microbial Fuel Cell for Voltage Generation from Biowaste. J Bioprocess Biotech 5: 246 . 